\title{
Sustainable Dyeing of Microwave Treated Polyester Fabric using Disperse Yellow 211 Dye
}

\author{
Shahid Adeel ${ }^{1}$, Samreen Gul Khan*1, Sania Shahid ${ }^{1}$, Muhammad Saeed ${ }^{1}$, Shumaila Kiran², \\ Muhammad Zuber ${ }^{2}$, Muhammad Suleman ${ }^{3}$, Nasim Akhtar ${ }^{4}$. \\ ${ }^{1}$ Department of Chemistry, Government College University Faisalabad 38000, Pakistan \\ ${ }^{2}$ Department of Applied Chemistry and Biochemistry, Government College University Faisalabad \\ 38000, Pakistan \\ ${ }^{3}$ Department of Chemistry, Women University of Azad Jammu \& Kashmir, Bagh Pakistan \\ ${ }^{4}$ Nuclear Institute for Agriculture and Biology, Jhang Road Faisalabad Pakistan \\ *Corresponding Author: samreengul@gcuf.edu.pk (S. G. Khan*). Phone: +92-41-9200037, \\ $+92-333-8353706$
}

Received May 8" ${ }^{\text {th }}$ 2017; Accepted December 26 ${ }^{\text {th }}, 2017$.

DOI: http://dx.doi.org/10.29356/jmcs.v62i1.580

\begin{abstract}
The aim of current work is to evaluate the dyeing performance of newly introduced disperse dye to improve its dyeing behavior onto polyester fabric using microwave radiation. Microwave heating has promisingly improved the disperse dyeing of polyester fabrics. Disperse Yellow 211 (DY 211) has been used to dye the polyester fabric under the influence of microwave treatment. Both the fabric and dye solution, were treated with the microwaves for 1- $6 \mathrm{~min}$. Different dyeing parameters such as temperature, time, dispersant and dye bath volume were also optimized and ISO standard methods for colorfastness were employed to rate the influence of microwave and ultraviolet treatment on disperse dyeing. It is found that microwave treated polyester (RP, $6 \mathrm{~min}$ ), has given good color strength and darker shades upon dyeing at $90^{\circ} \mathrm{C}$ for $40 \mathrm{~min}$. in the presence of $2 \mathrm{~g} / 100 \mathrm{ml}$ of dispersant using $70 \mathrm{~mL}$ of irradiated dye solution (RS, 6 min) of $\mathrm{pH}$ 8. Similarly using dye bath of $\mathrm{pH} \mathrm{11,} \mathrm{microwave} \mathrm{treated}$ polyester (RP, 6 min.) has given good color strength and darker shades upon dyeing at $70^{\circ} \mathrm{C}$ for 35 min.in the presence of $1 \mathrm{~g} / 100 \mathrm{ml}$ of dispersant. using $50 \mathrm{~mL}$ of irradiated dye solution (RS). ISO standards for fastness to light, washing and rubbing revealed that good to excellent ratings have been obtained from different shades dyed at optimal condition. It is inferred that Microwave treatment has not only reduced the dyeing conditions but also improved the color characteristics of dyed polyester fabric.
\end{abstract}

Key words: Disperse Yellow 211; Colorfastness Properties; Polyester fabric; Microwave Irradiation; Spectra flash SF600; Dispersant; Crock meter.

Resumen. El objetivo del presente trabajo es evaluar las características que se inducen al teñido sobre tejido base poliéster, después de habérsele aplicado radiación de microondas, evaluando para ello las propiedades del tinte recién disperso en la fibra. Se observa que el calentamiento por microondas mejora de manera adecuada la dispersión del teñido en telas base poliéster. Para las pruebas se utilizó el colorante textil Amarillo Disperso 211 (DY 211) para teñir el tejido base poliéster, bajo la influencia del tratamiento con microondas. Tanto al tejido como a la solución del tinte se les hizo un tratamiento con microondas durante 1-6 min. También se optimizaron diferentes parámetros de teñido, tales como la temperatura, el tiempo, el dispersante y el volumen del baño de colorante; se efectuaron análisis de las muestras utilizando los métodos estándares ISO para evaluar el efecto en la solidez del color en el teñido disperso por el tratamiento con microondas y radiación ultravioleta. Se encontró que el poliéster tratado con microondas (RP, 6 min), presenta una buena adhesión del color y produce tonos más oscuros al teñir a una temperatura de $90^{\circ} \mathrm{C}$ durante $40 \mathrm{~min}$. en presencia de $2 \mathrm{~g} / 100 \mathrm{ml}$ del dispersante, usando para ello $70 \mathrm{ml}$ de solución de colorante irradiado (RS, $6 \mathrm{~min}$ ) a un $\mathrm{pH}=8$. De manera similar, utilizando un baño de colorante a $\mathrm{pH}=11$, el poliéster tratado con microondas (RP, $6 \mathrm{~min}$ ) da lugar a un color resistente y produce tonos más oscuros al teñir a $70^{\circ} \mathrm{C}$ durante 35 minutos en presencia de $1 \mathrm{~g} / 100 \mathrm{ml}$ de dispersante. usando $50 \mathrm{ml}$ de solución de colorante irradiado (RS). Las pruebas de solidez a la luz, lavado y el frotamiento hechas mediante métodos ISO revelaron que se han obtenido clasificaciones de buenas a excelentes de los diferentes tonos teñidos en condiciones óptimas. Se infiere que el tratamiento con microondas no solo ha reducido los requerimientos para el teñido, sino que también ha mejorado las características del color sobre la tela de poliéster teñida.

Palabras clave: Amarillo disperso 211; Propiedades de solidez de color, Tejido de poliéster; Irradiación con microondas; Spectra flash SF600; Dispersante; Medición del color transferido al material textil. 


\section{Introduction}

Synthetic dyes are highly colored substances which are extensively used to dye textile, cosmetic, color photocopy, pharmaceutical papers, wood and fiber etc. These dyes contain such functional groups which form the covalent bond with active sites of fabrics. Of these synthetic dyes, disperse dyes have their own uniqueness and method of application. These are especially used to dye polyester, polyamide and acetate fabrics [1, 2]. It is essential for disperse dyes to have ability to resist change in various dyeing conditions such as $\mathrm{pH}$ and temperature that results in negligible changes in shade and fastness which is due to the absence or presence of solubilizing groups and low molecular weight dye [3]. Disperse dyes are very popular and an important class of dyes for dyeing polyester fabrics owing to their luster, wide range of color and excellent fastness properties, as well as the environmental and economic point of view.

From chemical point of view, disperse dyes are classified as either nitroarylamine, azo, or anthra-quinone [4]. The most dominant group among disperse dyes is the azo disperse dyes which are about $70 \%$ of all disperse dyes manufactured. These are originally developed to dye cellulose acetate and all other aqua phobic fibers such as polyester. Dyeing of polyester is a complex matter because it does not have reactive surface sites. It only has $4 \%$ low moisture region and poor ability to hold water and dyes [5-7]. It is usually dyed with disperse dyes because of their high tinctorial strength and good fastness properties. Polyester fabric is more readily dyed by using different techniques of dyeing at high temperature or in the presence of swelling agents or carriers [8].

In current study Disperse Yellow 211 (DY 211) was selected for dyeing of polyester under the influence of microwave and ultraviolet radiation. Disperse Yellow 211 (DY 211) is bright yellow dye having pH ranges from 4 to 6 (Structure given below). It is mostly used in textile and paper industry. It shows excellent dispersion and compatibility with fabric that gives good color characteristics.

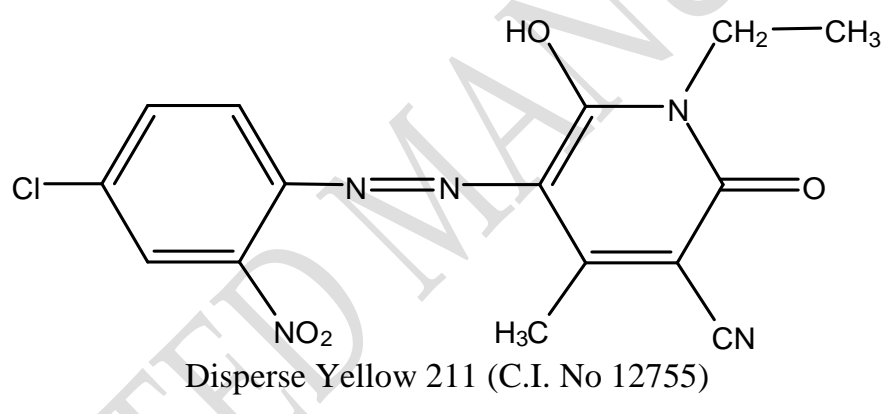

To improve the uptake ability of fabrics using disperse dye, various techniques [9] are being used such as UV [10], Gamma [11,12], Plasma [13], Microwave and Ultrasonic treatment [14]. Microwave radiation is a potential, swift and ecofriendly heating source. It is used in different textile process such as fabric dyeing and finishing processes etc. Microwave radiations increase the reaction rate which yield high productivity of dyes through even or constant heating. In the disperse dyeing of polyester fabrics the use of microwave heating treatment encourage the dye exhaustion and the dyeing rates. Dielectric heating by microwave can be explained based on phenomenon of conversion of energy from wave into thermal form in the dielectric materials. Materials with high dielectric constants, such as water, salt, and alcohol, can be self-heated by the rotation and relaxation of dipole during the radiation of microwave [15]. Hence keeping in view, the sustainable advantages of microwave treatment in disperse dyeing of polyester fabric, the current study is aimed for microwave assisted improvement in color strength and fastness properties polyester fabric using disperde Yellow 211 dye_under mild condition.

\section{Results and Discussion}

\section{Effect of microwave treatment on dyeing}

The role of microwave treatment in polyester dyeing is very promising because it makes the process ecofriendly as well as cost, time and labor effective [16]. This sustainable nature of microwave treatment in disperse dyeing has been proved in this situation. The result given in Fig. 1a using the dye bath of $\mathrm{pH} 8$ and in Fig. 1b using dye bath of $\mathrm{pH} 11$ show that high K/S is obtained by dyeing irradiated polyester fabrics (RP) using the irradiated solution of Disperse Yellow 211 (RS) after microwave treatment for $6 \mathrm{~min}$. Microwave treatment is a volumetric heating, so the materials absorb 
Article

J. Mex. Chem. Soc. 2018, 62(1)

(C)2018, Sociedad Química de México

ISSN-e 2594-0317

ISSN 1870-249X

energy directly and internally that leads to advantages such as rapid, controlled, selective and uniform heating. Good K/S is obtained because during microwave heating, the surface of polyester is evenly tuned, which helps to modify the fabric to make the significant interaction with dye [17]. Also, the molecules of disperse dye are large enough to penetrate into fibers and after the microwave treatment the cluster of molecules are disintegrate into small size that make them viable to sorb into the voids of fabric [18-20]. Thus, after dyeing, upon washing, less color is detached and good K/S with acceptable fastness is observed. At low microwave heating time, the voids are unable to open and dye molecules being bigger in size cannot be penetrate, while for long time heating the equilibrium of dye bath is disturbed and rushed towards dye bath resulting in low color depth [21, 22]. Hence it is recommended that dyeing of polyester fabric should be done after microwave treatment for 6 minutes.

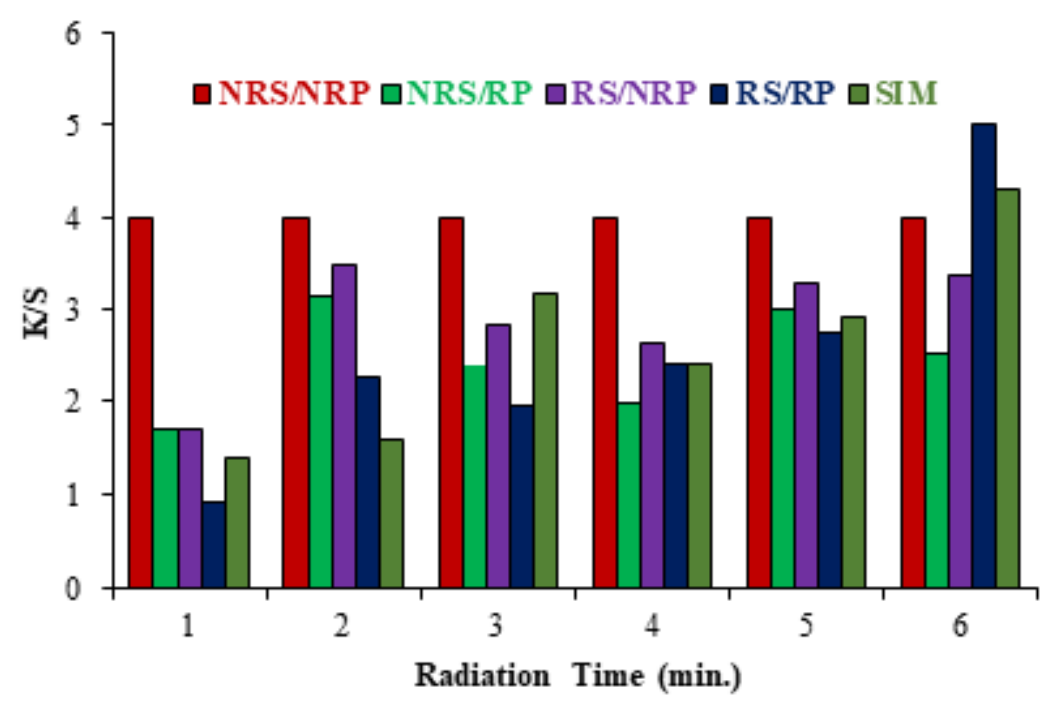

Fig. 1a. Effect of microwave treatment on dyeing of polyester fabrics at pH 8 using Disperse Yellow 211.

$(\mathrm{NRP}=$ Non Radiate Polyester RP =Radiate Polyester NRS $=$ Non Radiate Solution $\quad$ RS= Radiate Solution)

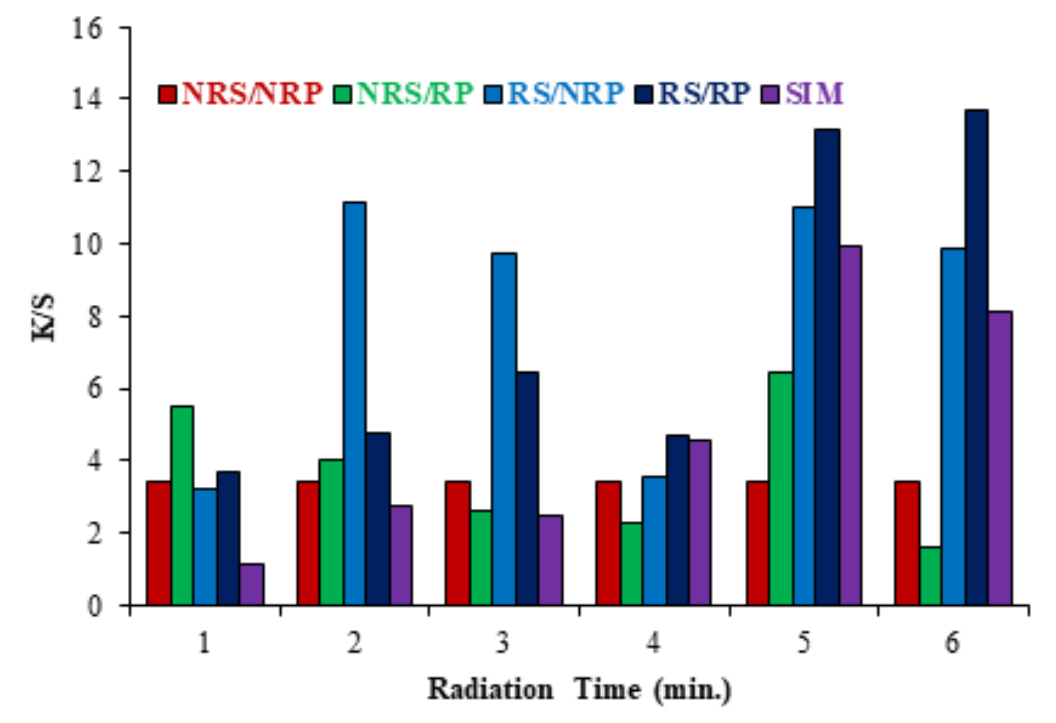


Article

J. Mex. Chem. Soc. 2018, 62(1)

(C)2018, Sociedad Química de México

ISSN-e 2594-0317

ISSN 1870-249X

Fig. 1b. Effect of microwave treatment on dyeing of polyester fabrics at pH 8 (a) and pH 11 (b) using Disperse Yellow 211.

\section{Effect of temperature on dyeing}

Mostly disperse dyeing is carried out at $110-140^{\circ} \mathrm{C}$ but microwave treatment for both fabric and solution (RS/RP) at $\mathrm{pH} 8$ and 11 has made it more convenient to dye at lower temperature Fig. 2 Dyeing of irradiated polyester (RP) for $6 \mathrm{~min}$. at $90^{\circ} \mathrm{C}$ using the dye bath at $\mathrm{pH} 8$ has shown good $\mathrm{K} / \mathrm{S}$ and acceptable fastness. Dyeing temperature varies from dye to dye, the larger the structure of dye, more heating is required for interaction with active sites of fabric. However, all disperse dyes exhaust well at or below $117^{\circ} \mathrm{C}$ and a little higher temperature is maintained to compensate heat loss and better migration of dye molecules for leveled shades. At low temperature, the molecules are not accelerated enough to move towards the fabric while after irradiation, the dyeing above optimum temperature, the desorption is favored and even under alkaline condition $\mathrm{pH} 11$ the rate of dyeing is reversed, and the dye may face disturbance in stability at onto fabrics resulting in low K/S and low rating of fastness characteristics. Hence on account of dyeing temperature, using media of dye bath $(\mathrm{pH} 8), 90^{\circ} \mathrm{C}$ is

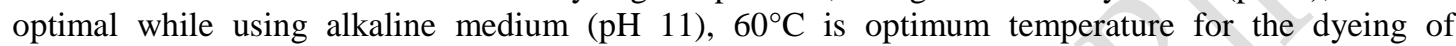
irradiated polyester. Hence microwave treatment has reduced the temperature of dye bath, which reveals that is is energy effective tool too.

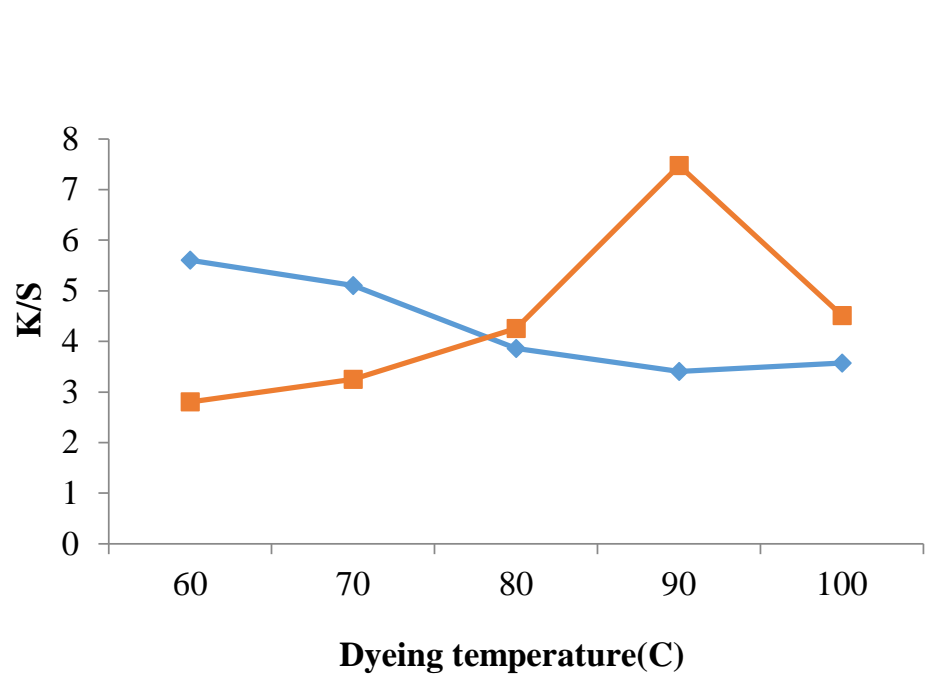

Fig. 2. Impact of temperature on dyeing of polyester fabric using Disperse Yellow 211.

\section{Effect of time on dyeing}

Contact time is very important in disperse dyeing as it makes the equilibrium between dyeing bath and fabric after irradiation for $6 \mathrm{~min}$. Again, the used medium plays its role because under $\mathrm{pH} 8,35$ min. is optimum dyeing time while using alkaline bath ( $\mathrm{pH} \mathrm{11),} 40 \mathrm{~min}$. is the optimal contact time. This is because dyeing for short time does not accelerate the molecules, while heating for long time may cause stripping and equilibrium is favored towards dye bath. The results displayed in Fig. 3 shows that in both cases, the dyeing time have been revealed after Microwave treatment of both solution and fabric for 6 min. Hence microwave treatment to both solution and fabric has been proven cost and time effective, which in turn is helpful to save labor, money and energy. 


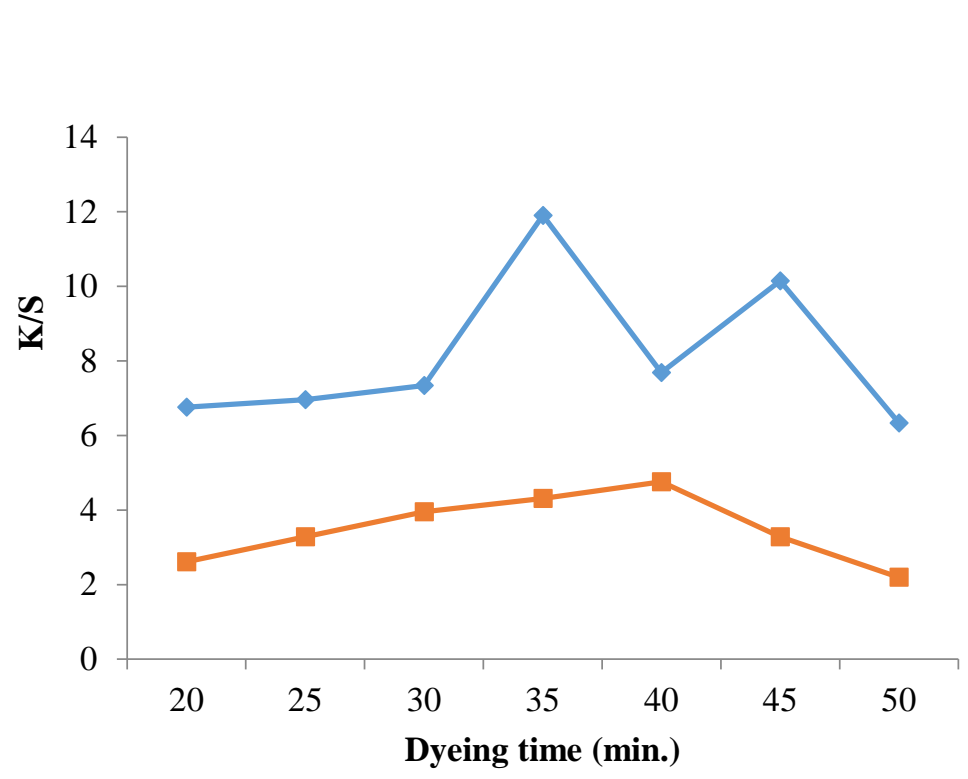

Fig. 3. Effect of time on dyeing of polyester fabric using Disperse Yellow 211.

\section{Effect of amount of dispersant on dyeing}

Dispersant amount is necessary for dispersed dyeing because it adds value in proper dispersion of dye solution to make it able for even interaction with polyester fabric. Dispersing agent imposes negative charge on dye to improve its aqueous solubility and inhibits the formation of dye cluster through repulsion among negatively charged dye molecules, retains dye in consistent dispersion throughout dyeing by enclosing single dye particle with a protective film. More the dispersant amount added, the more is the even dyeing. But over amount causes unevenness and aggregation in cluster on fabric surface to make dyeing process dull [23]. The results given in Fig. 4 shows that $2 \mathrm{~g}$ is optimum amount for dyeing of irradiated polyester and irradiated dye solution (RP/RS $6 \mathrm{~min}$.) in dye bath of $\mathrm{pH}$ 8, while for alkaline medium ( $\mathrm{pH} \mathrm{11),} 1 \mathrm{~g}$ is optimum amount for maximum color strength. The reduction in amount of dispersant shows that it is cost effective tool to be employed for disperse dyeing of polyester using disperse yellow dye 211 .

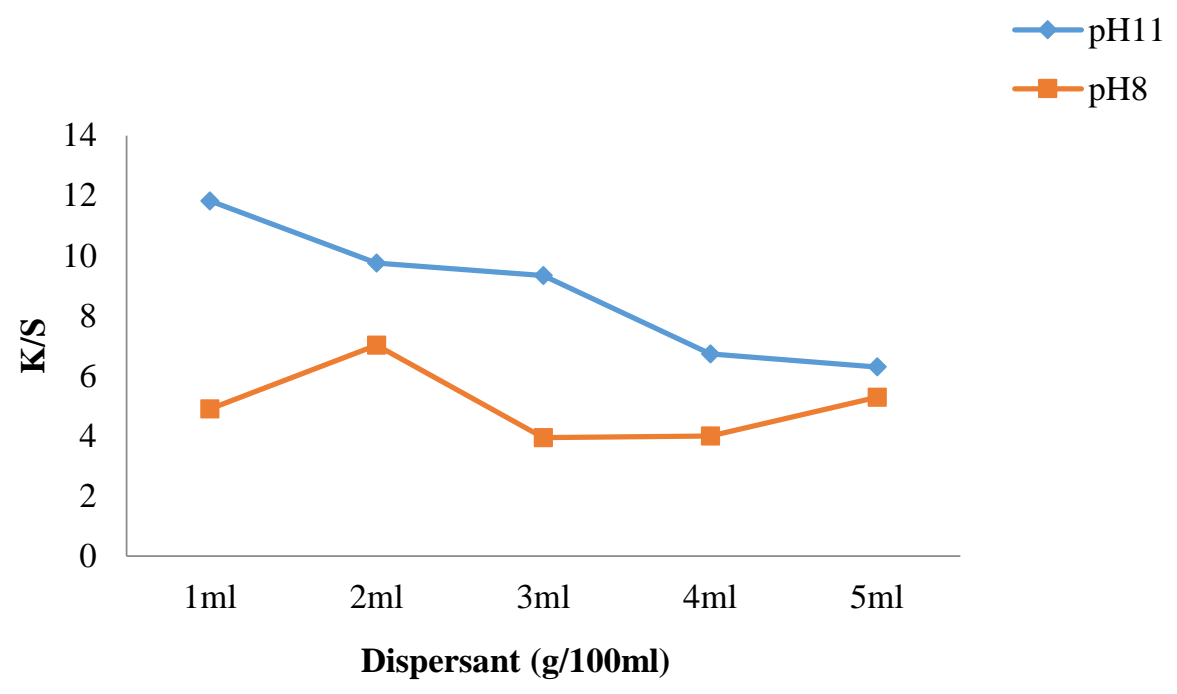

Fig. 4. Effect of dispersant on k/s value of fabric dyed with Disperse Yellow 211. 


\section{Effect of dye bath volume on dyeing}

The volume of dye bath also has a promising effect because microwave treatment adds significant contribution on disperse dyeing using Disperse Yellow 211 (DY 211). The results given in Fig. 5 show that at $\mathrm{pH} 8,70 \mathrm{~mL}$, while at $\mathrm{pH} 11,50 \mathrm{~mL}$ of dye bath is optimum volume to get high $\mathrm{K} / \mathrm{S}$ and acceptable fastness characteristics. Hence comparatively, $\mathrm{pH} 8$ is more suitable for getting darker shades [24].

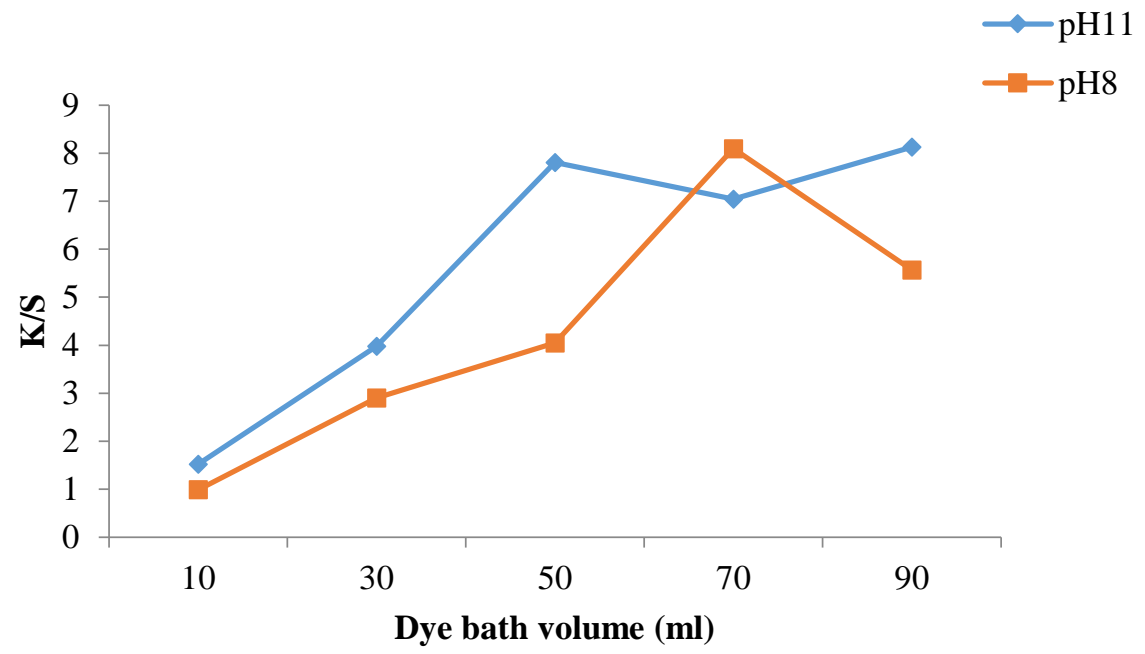

Fig. 5. Effect of dye bath volume on k/s value of fabric dyed with Disperse Yellow 211.

\section{Effect of microwave treatment on colorfastness properties of polyester fabrics dyed at pH 8 \& pH 11}

The rating results given in Table 1 (a \& b) show that dyeing of polyester fabric with Disperse Yellow 211 (DY 211) using the microwave radiation has given good results. The good light fastness is attributed to the presence of auxochrome such as $-\mathrm{NO}_{2},-\mathrm{CN},-\mathrm{OH}$ and the benzenoid structure as well as conjugation system that adds value in resistance towards fading. Similarly, the formation of covalent bonding with irradiated polyester due to polarization by microwave treatment for 6 min. also becomes helpful in strong interaction of functional sites of dye with fabric. Upon rubbing the fabric of variable shade (0.1- 4) the dyed fabric has shown profound resistance towards detaching. Hence the irradiated polyester fabrics (RP 6 min.) dyed using irradiated dye solution (RS, 6 min.) pH 8 \& pH 11 have given good to excellent fastness properties under the influence of microwave treatment.

Table 1(a). Effect of microwave treatment on colorfastness properties of polyester fabrics dyed at $\mathrm{pH}$ 8.

\begin{tabular}{|c|c|c|c|c|c|}
\hline \multirow{2}{*}{ Shade obtained } & \multirow{2}{*}{$\begin{array}{l}\text { Light } \\
\text { Fastness }\end{array}$} & \multicolumn{2}{|c|}{ Wash Fastness } & \multirow{2}{*}{$\begin{array}{l}\text { Dry } \\
\text { Rubbing } \\
\text { Fastness }\end{array}$} & \multirow{2}{*}{$\begin{array}{l}\text { Wet } \\
\text { Rubbing } \\
\text { Fastness }\end{array}$} \\
\hline & & $\begin{array}{l}\text { Color } \\
\text { change }\end{array}$ & $\begin{array}{l}\text { Color } \\
\text { staining }\end{array}$ & & \\
\hline control & $4 / 5$ & $3 / 4$ & $4 / 5$ & 4 & 4 \\
\hline 0.1 & $4 / 5$ & 3 & $3 / 4$ & $4 / 5$ & $4 / 5$ \\
\hline 0.5 & $4 / 5$ & $3 / 4$ & $3 / 4$ & $3 / 4$ & $3 / 4$ \\
\hline
\end{tabular}




\begin{tabular}{lccccc}
\hline 1 & $4 / 5$ & $3 / 4$ & $4 / 5$ & $4 / 5$ & $4 / 5$ \\
2 & $4 / 5$ & 4 & $3 / 4$ & $4 / 5$ & $4 / 5$ \\
3 & 4 & $3 / 4$ & $3 / 4$ & 4 & $4 / 5$ \\
4 & $4 / 5$ & $3 / 4$ & $3 / 4$ & 5 & 5 \\
\hline
\end{tabular}

Table 1(b). Effect of microwave treatment on colorfastness properties of polyester fabrics dyed at $\mathrm{pH}$ 11.

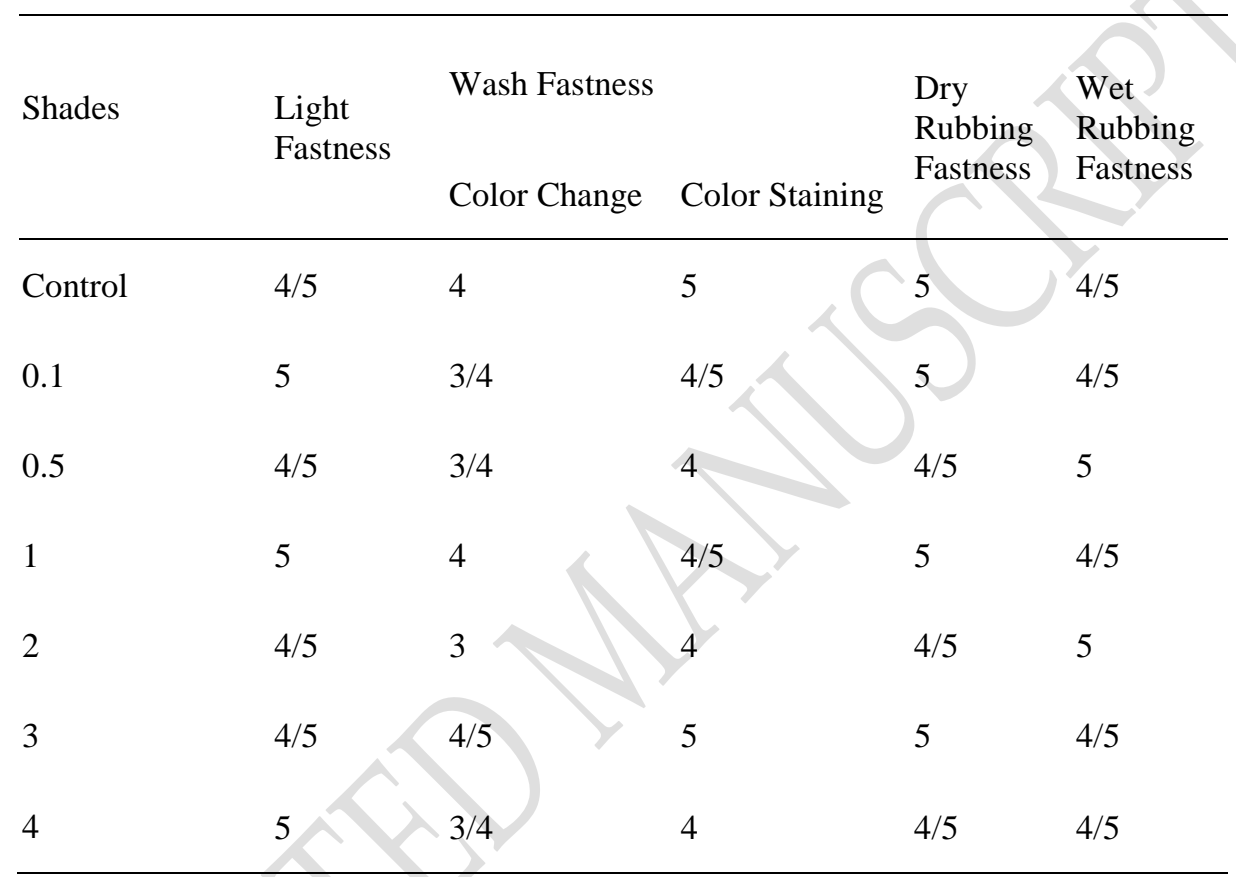

\section{Conclusions}

Microwave irradiation treatment has improved the color strength values of the irradiated polyester fabrics by the application of disperses dye. It is observed that good color strength and fastness properties could be obtained. If irradiated polyester (6 min.) is dyed at $90^{\circ} \mathrm{C}$ for $40 \mathrm{~min}$. using media of $\mathrm{pH} 8$ in the presence of $2 \mathrm{~g} / 100 \mathrm{ml}$ dispersant using irradiated disperse dye solution as compared to dyeing of irradiated polyester (6 min.) at $70^{\circ} \mathrm{C}$ for $35 \mathrm{~min}$. using dyeing media of $\mathrm{pH} 11$ in the presence of $1 \mathrm{~g} / 100 \mathrm{ml}$ of dispersing agent using irradiated disperse dye solution. Thus, microwave radiation can be successfully applied to enhance the color fastness properties as well as color strength without harming the chemical characteristics of polyester fabric.

\section{Experimental Section}

\section{Irradiation Process}

Disperse Yellow 211 (DY 211) (C.I. No 12755) and polyester fabrics were procured from local Textile market Faisalabad, Pakistan. Polyester fabrics and dye solution were exposed to microwave radiation using commercially available oven of Orient Company (700 watt \& $2450 \mathrm{MHz}$ ) for 1, 2, 3, 4, 5 and 6 min. respectively at Department of Chemistry from Govt. College University Faisalabad, 
Pakistan. All the chemicals used during the dyeing were of commercial grade. Dyeing of un- irradiated polyester (NRP) and irradiated polyester fabrics (RP) were carried out at $90^{\circ} \mathrm{C}$ for 35 min. keeping $\mathrm{M}: \mathrm{L}$ 1:30 using irradiated (RS )and un-irradiated dye solution (NRS ).

\section{Optimization of Different Dyeing Condition}

In order to optimize the dyeing parameters using optimal condition of microwave radiation, dyeing was carried out at different time of 10 to $60 \mathrm{~min}$. To observe the effect of $\mathrm{pH}$ on dyeing, the optical fabrics were carried out at different $\mathrm{pH}$ values $(8,11)$. In another experiment dyeing of irradiated polyester fabrics was carried out to evaluate the effect of dispersing agent using different concentrations of 1 to $6 \mathrm{~mL}$ of dispersant. All the dyeing processes were carried out at $90^{\circ} \mathrm{C}$ for $45 \mathrm{~min}$. Keeping M:L of 1:25.

\section{Evaluation of Quality of Dyed Fabrics}

The color strengths, (K/S) values of the un-irradiated fabric (NRP) and irradiated polyester fabrics (RP) using irradiated dye solution (RS) and un-irradiated solution (NRS) were investigated in CIE Lab system through the given Kubelka-Munk equation computed in spectra flash (SF 600) equipped with an illuminate of D $6510^{\circ}$ observer at Department of Applied Chemistry Government College University, Faisalabad.

$$
\mathrm{K} / \mathrm{S}=(1-\mathrm{R})^{2} / 2 \mathrm{R}
$$

The effect of microwave radiation on colorfastness properties such as colorfastness to light, washing and rubbing was determined. Standard methods of ISO such as ISO 105 CO3 for washing fastness, ISO 105 X-12 for rubbing and ISO 105 BO2 for light fastness were applied [11].

\section{Acknowledgements}

We are grateful to Higher Education Commission of Pakistan (HEC) for funding the project (No. 20-2724/NRPU/R\&D/HEC/12/6828). We are also thankful to Mr. Zafar Iqbal Manger QA \& QC of Noor Fatima Textile (Pvt.) Limited, Faisalabad Pakistan and Mr. Arshad Mayo, Sohaib Dyes and Chemical (Pvt.) Limited, Faisalabad for providing the technical assistance and implementation of the work at industrial scale.

\section{References}

1. Bhatti, I. A.; Adeel, S.; Parveen, S.; Zuber, M. J Saudi Chem Soc. 2016, 20, 178-184.

2. Adeel, S.; Azeem, M.; Kamal, S.; Rehman, F.; Ghaffar, A.; Habib, N.; Shabir, A. U. Oxid Commun. 2016, 39, 3507-3514.

3. Kale, M. J.; Bhat, N. V. Color Technol. 2011, 127, 365-371.

4. Metwally, M. A.; Abdel-Galil, E.; Metwally, A.; Amer, F. A. Dyes Pigments. 2012, 92, 902-908.

5. Shah, T. B.; Shiny, R. S.; Dixit, R. B.; Dixit, B. C. J Saudi Chem Soc. 2014, 18, 985-992.

6. Elabid, A. E.; Zhang, J., Shi, J.; Guo, Y., Ding, K.; Zhang, J. Applied Surface Sci. 2016, 375, $26-34$.

7. Zhang, X. N.; Mao, G. Y.; Jiao, Y. B.; Shang, Y.; Han, R. P. Int J Environ Sci Tech. 2014, 11, 1439-1448.

8. Younis, A. A. Egyptian J Petrol. 2016, 25, 161-169.

9. Zhang, Y.; Li, Y.; Hu, Q. Int J Cloth Sci Tech. 2012, 24, 118-128.

10. Rehman, F.; Adeel, S.; Hanif, R.; Muneer, M.; Zia, K. M.; Zuber, M.; Khosa, M. K. J Nat Fibers. 2017, 14, 63-70.

11. Adeel, S.; Gulzar, T.; Azeem, M.; Saeed, M.; Hanif, I.; Iqbal, N. Radiat Phys Chem. 2017, 130, 35-39.

12. Zahid, M.; Bhatti, I. A.; Adeel, S.; Saba, S. J Text I. 2017, 108, 287-292.

13. Vellingiri, K.; Ramachandran, T.; Senthilkumar, P. Int J Cloth SciTech. 2014, 26, 456-479.

14. Abdel-Thalouth, I.; Ragheb, A. A.; Rekaby, M.; El-Hennawi, H. M.; Shahin, A. A.; Haggag, K. Res. J. Chem. Sci. 2014, 4,41-46.

15. Al-Mousawi, S. M.; El-Apasery, M. A.; \& Mahmoud, H. M. Molecules. 2013, 18, 7081-7092.

16. J.N.Chakarborty. Woodhead Publishing Cambridge, UK. 2013, 222-232.

17. Kappe, C. O.; Dallinger, D. Molecular Diversity. 2009, 13, 71.

18. N. V.; Kale, M. J.; Gore, A. V. J Eng Fibers Fabrics. 2009, 4, 1-6.

19. Öner, E.; Büyükakinci, Y.; Sökmen, N. Color Technol. 2013, 129,125-130.

20. Chiao-Cheng, J. H.; Reagan, B. M. Textile Chemist \& Colorist. 1983, 15, 29- 36. 
Article

J. Mex. Chem. Soc. 2018, 62(1)

(C)2018, Sociedad Química de México

ISSN-e 2594-0317

ISSN 1870-249X

21. Kamel, M. M.; Allam, O. G.; El-Gabry, L. K.; Helmy, H. M. J Appl Sci Res. 2013, 9, 3520-3529.

22. El-Molla, M. M.; Haggag, K.; Ahmed, K. A. Int J Sci Res. 2013, 4, 2319- 7064.

23. Adeel, S.; Usman, M.; Haider, W.; Saeed, M.; Muneer, M.; Ali, M. Cellulose. 2015, 22, 2095-2105.

24. Saeed, M.; Adeel, S.; Ilyas, M.; Shahzad, M. A.; Usman, M.; Haq, E. U.; Hamayun, M. Desalin Water Treat. 2016, 57, 12804-12813. 